\title{
Prevention of diabetic nephropathy with enalapril in normotensive diabetics with microalbuminuria
}

\author{
Michel Marre, Gilles Chatellier, Hervé Leblanc, Tam Than Guyene, Joël Menard, Philippe Passa
}

Abstract

Study objective-To assess the effectiveness of inhibition of angiotensin converting enzyme in preventing diabetic nephropathy.

Design-Randomised follow up study of normotensive diabetics with persistent microalbuminuria (30-300 $\mathrm{mg} / 24$ hours) treated with enalapril or its matched placebo for one year. Double blind for first six months, single blind for last six months.

Setting-Diabetic clinic in tertiary referral centre.

Patients-Treatment group and placebo group each comprised 10 normotensive diabetics with persistent microalbuminuria.

Interventions - Treatment group was given enalapril $20 \mathrm{mg}$ daily and controls matched placebo. Patients were given antihypertensive treatment after one year.

End point-Albumin excretion, arterial pressure, and renal function.

Main results - In last three months of trial three of 10 patients taking placebo had diabetic nephropathy (albumin excretion $>\mathbf{3 0 0} \mathbf{~ m g} / \mathbf{2 4}$ hours). No patients taking enalapril developed nephropathy and five showed normal albumin excretion $(<30 \mathrm{mg} / 24$ hours) $(p=0.005$, Mann-Whitney test). Mean arterial pressure was reduced by enalapril throughout study $(p<0.005)$ but increased linearly with placebo $(p<0.05)$. Albumin excretion decreased linearly with enalapril but not placebo. An increase in albumin excretion with placebo was positively related to the increase in mean arterial pressure $(r=0.709, p<0.05$, Spearman's rank test). With enalapril total renal resistances and fractional albumin clearances improved progressively (time effect, $p=0.0001$ ).

Conclusion-Inhibition of angiotensin converting enzyme prevents development of nephropathy in normotensive diabetics with persistent microalbuminuria. This may be due to reduction in intraglomerular pressure and to prevention of increased systemic blood pressure. Future studies should compare long term effects of inhibitors of converting enzyme with other antihypertensive drugs.

Service de Diabétologie, Hôpital Saint-Louis, 75475 Paris, Cedex 10, France Michel Marre, MD, registrar Hervé Leblanc, MD, registrar Philippe Passa, MD, professor

Service d'Informatique Médicale, Hôpital de la Pitié-Salpêtrière, 75013 Paris, France Gilles Chatellier, MD, registrar

\section{INSERM U36, 75005 Paris,} France

Tam Than Guyene, MD, senior registrar

Joël Menard, MD, professor

Correspondence to: $\operatorname{Dr} M$ Marre, Service de Médecine B, Centre Hospitalier

Universitaire, 49000 Angers, France. from developing. ${ }^{7}$ Also the selection criteria proposed for this treatment make large scale treatment of insulin dependent diabetics difficult. ${ }^{8}$ Restriction of dietary protein can reduce albumin excretion in diabetics, ${ }^{9}$ but clinical data do not suggest that patients can comply with such a diet for long periods. Conversely, early antihypertensive treatment can alter the course of albumin excretion at the stage of incipient diabetic nephropathy. ${ }^{10}$

We have shown by a six month randomised, placebo controlled, double blind study that a reduction in blood pressure by inhibition of angiotensin converting enzyme reduces albumin excretion in normotensive diabetics with persistent microalbuminuria." We followed up all of these patients to one year to observe the effects of long term inhibition of angiotensin converting enzyme in preventing the development of diabetic nephropathy.

\section{Patients and methods}

\section{PATIENTS AND STUDY PROTOCOL}

Two groups of 10 ambulant patients were entered into the study if they were aged 20-60; had had diabetes for more than five years; were not obese; had persistent microalbuminuria (albumin excretion rate $30-300 \mathrm{mg} / 24$ hours recorded twice or three times over three months) ${ }^{12}$ but no hypertension (according to the criteria of the World Health Organisation $)^{13}$; and their metabolic control was stable, with a total haemoglobin $\mathrm{A}_{1 \mathrm{c}}$ concentration below $10 \%$. Details of their individual characteristics and treatments have been published." The dietary instructions and antidiabetic treatment at the beginning of the trial remained unchanged during the follow up.

After a three month pretreatment period the patients were allocated in pairs to receive treatment for one year with either $20 \mathrm{mg}$ enalapril daily or its matched placebo. The randomisation schedule and the instructions given to the patients have been reported. ${ }^{.1}$ The patients were entered into the study over six months. The 10 patients entered into the trial first were followed up double blind; two had persistent proteinuria and blood pressures above $140 / 90 \mathrm{~mm} \mathrm{Hg}$ at the end of the one year treatment. As antihypertensive treatment must be instituted promptly in such patients $\mathrm{s}^{14-16}$ the double blind code was disrupted, and the two patients, who had been treated with placebo, were given antihypertensive drugs. Therefore, the last 10 patients recruited were followed up blind during the last six months of the trial. One of them, who developed persistent proteinuria, was given antihypertensive treatment after one year of treatment with placebo.

During both the pretreatment and treatment periods mean arterial pressure and albumin excretion rate were measured monthly and total glycated haemoglobin every two months. Kidney function was investigated at the end of the pretreatment period and after six and 12 months of treatment.

\section{METHODS}

Mean arterial pressure was measured with patients supine every three minutes for 30 minutes with an automatic device (Dinamap, Critikon, Florida, United States; cuff size $23-13 \times 13 \mathrm{~cm}$ ) between 0900 and 1100 . Albumin excretion rate was measured by radio- 
immunoassay on 24 hour samples of urine. ${ }^{17}$ Values below $30 \mathrm{mg}$ albumin/24 hours were considered to be in the normal range, and values of $30-300 \mathrm{mg}$ albumin/ 24 hours or $>300 \mathrm{mg}$ albumin/24 hours to represent persistent microalbuminuria or persistent macroalbuminuria respectively if obtained twice or three times over three months. Values greater than $300 \mathrm{mg}$ albumin $/ 24$ hours indicated clinical proteinuria. ${ }^{12}$ Total glycated haemoglobin was measured with a Cordis kit (mean control value $6 \cdot 1$ (SD) $0 \cdot 5 \%$ ).

To assess kidney function the patients reported, fasting, at 0700 . Constant diuresis was induced by progressive water loading, and after at least one hour of constant diuresis glomerular filtration rate and effective renal plasma flow were estimated by urinary clearances of iodothalamate labelled with iodine-125 and hippurate labelled with iodine-131 (Amersham Laboratories), respectively. ${ }^{18}$ The values were adjusted to a body surface area of $1.73 \mathrm{~m}^{2}$. The filtration fraction was calculated as glomerular filtration rate/effective renal plasma flow, and the total renal resistances were calculated as mean arterial pressure during clearance/ effective renal plasma flow. Serum albumin concentration was measured by laser nephelometry. The fractional albumin clearance was calculated as urinary albumin clearance/glomerular filtration rate. Plasma glucose concentration was measured with a glucose oxidase method during the clearance studies and recorded as a mean of six measurements. The mean (range) control values of all variables have been reported."

Urinary sodium and serum potassium concentrations were measured with flame photometry and urinary urea by a urease method. Total and active renin concentrations were measured by direct immunoradiometry ${ }^{19}$ in samples of plasma collected with the patients supine on the day of testing kidney function.

\section{STATISTICAL ANALYSIS}

Results are expressed as means (SEM), or as median and range values. Effects of the treatment and its duration were assessed by two way repeated measures analysis of variance. When a significant interaction between duration and treatment was found the results were assessed separately in each group by one way repeated measures analysis of variance. As linear regression was not a valid method for this study we assessed the linearity of any relation between duration of treatment and the other criteria by analysis of variance; the program of the biomedical programs

TABLE I-Measurements of weight and biochemical variables during trial in normotensive diabetics receiving enalapril or placebo

\begin{tabular}{|c|c|c|c|}
\hline & \multicolumn{3}{|c|}{ Time during trial (months) } \\
\hline & 0 & 6 & 12 \\
\hline \multicolumn{4}{|c|}{ Median (range) weight $(\mathbf{k g})$ : } \\
\hline Placebo & $70(46-98)$ & $71(46-97)$ & $70(46-95)$ \\
\hline Enalapril & $67(45-85)$ & $67(46-87)$ & $68(44-85)$ \\
\hline \multicolumn{4}{|c|}{ Median (range) serum potassium $(\mathrm{mmol} / \mathrm{l})$ : } \\
\hline Placebo & $4 \cdot 0(3 \cdot 6-4 \cdot 3)$ & $4 \cdot 1(3 \cdot 7-4 \cdot 7)$ & $4 \cdot 0(3 \cdot 7-4 \cdot 2)$ \\
\hline Enalapril & $4 \cdot 1(3 \cdot 7-5 \cdot 2)$ & $4 \cdot 1(3 \cdot 8-4 \cdot 9)$ & $4 \cdot 0(3 \cdot 8-4 \cdot 7)$ \\
\hline \multicolumn{4}{|c|}{ Median (range) urinary sodium $(\mathrm{mmol} / 24 \mathrm{~h})$ : } \\
\hline $\begin{array}{l}\text { Placebo } \\
\text { Pas }\end{array}$ & $98(66-161)$ & $113(66-152)$ & $118(52-179)$ \\
\hline Enalapril & $102(66-182)$ & $105(66-170)$ & $105(72-175)$ \\
\hline \multicolumn{4}{|c|}{ Median (range) urinary urea $(\mathrm{mmol} / 24 \mathrm{~h})$ : } \\
\hline Placebo & $228(148-720)$ & $228(160-697)$ & $240(125-702)$ \\
\hline Enalapril & $249(132-578)$ & $279(141-521)$ & $291(126-493)$ \\
\hline \multicolumn{4}{|c|}{ Mean (range) plasma glucose $(\mathrm{mmol} / \mathrm{l})$ : } \\
\hline Placebo & $7 \cdot 3(4 \cdot 1-11 \cdot 2)$ & $8 \cdot 3(4 \cdot 6-11 \cdot 5)$ & $7 \cdot 6(4 \cdot 3-11 \cdot 2)$ \\
\hline Enalapril & $6 \cdot 6(4 \cdot 8-10 \cdot 2)$ & $6 \cdot 7(4 \cdot 6-11 \cdot 0)$ & $7 \cdot 6(5 \cdot 1-9 \cdot 7)$ \\
\hline \multicolumn{4}{|c|}{ Mean (range) haemoglobin (\%): } \\
\hline Placebo & $8 \cdot 2(6 \cdot 2-9 \cdot 6)$ & $8 \cdot 4(7 \cdot 2 \cdot 10 \cdot 5)$ & $8 \cdot 8(7 \cdot 0-9 \cdot 7)$ \\
\hline Enalapril & $8 \cdot 1(7 \cdot 0-9 \cdot 7)$ & $8 \cdot 3(6 \cdot 6-11 \cdot 4)$ & $8 \cdot 3(7 \cdot 2-9 \cdot 8)$ \\
\hline \multicolumn{4}{|c|}{ Mean (range) active renin $(\mathrm{pmol} / \mathrm{l})$ : } \\
\hline Placebo & $0.5(0 \cdot 1-0.9)$ & $0.5(0 \cdot 1-1 \cdot 0)$ & $0 \cdot 4(0 \cdot 1-0 \cdot 7)$ \\
\hline Enalapril & $0 \cdot 6(0 \cdot 2-1 \cdot 2)$ & $1 \cdot 2(0 \cdot 4-9 \cdot 3)^{\star}$ & $2 \cdot 1(0 \cdot 7-10 \cdot 2)$ \\
\hline \multicolumn{4}{|c|}{ Total renin $(\mathrm{pmol} / \mathrm{l})$ : } \\
\hline Placebo & $6 \cdot 4(3 \cdot 7-9 \cdot 4)$ & $5 \cdot 7(3 \cdot 0-11 \cdot 0)$ & $6 \cdot 4(2 \cdot 8-11 \cdot 6)$ \\
\hline Enalapril & $6 \cdot 6(2 \cdot 3-20 \cdot 5)^{\star}$ & $13 \cdot 4(5 \cdot 5-30 \cdot 5)^{\star}$ & $16 \cdot 8(6 \cdot 0-28 \cdot 7)^{\star}$ \\
\hline
\end{tabular}

${ }^{\star} \mathrm{p}<0 \cdot 01$ Placebo $(\mathrm{n}=10) v$ enalapril $(\mathrm{n}=10)$. statistical package was used for all of the analyses. ${ }^{20}$ When the variance of the groups was unequal the original data were logarithmically transformed before the analysis. The correlation between two variables was estimated by Spearman's rank test. A non-parametric (Mann-Whitney U) test was used to compare the occurrence of diabetic nephropathy between the groups.

\section{Results}

As shown in table I weight, serum concentration of potassium, urinary excretion of sodium and urea, and mean plasma concentrations of glucose and $\mathrm{HbA}_{1 \mathrm{c}}$ did not vary either between the two groups or within each group throughout the study. The concentrations of active and total renin were significantly increased in the group receiving enalapril.

Albumin excretion was identical in both groups during the pretreatment period (analysis of variance $\left.\mathrm{F}_{18}^{1}=0.37, \mathrm{p}>0.1\right)$ but was significantly lower during the treatment with enalapril than placebo $\left(\mathrm{F}_{18}=5 \cdot 08\right.$, $\mathrm{p}=<0.05)$. There was a significant interaction between duration and treatment $\left(\mathrm{F}_{198}^{11}=4 \cdot 24, \mathrm{p}<0.0001\right)$. The change in albumin excretion was analysed in each group; with placebo the duration of treatment was significant, but the change was not linear, and with enalapril the rate declined significantly and linearly with time (fig 1, upper panels). During the last three

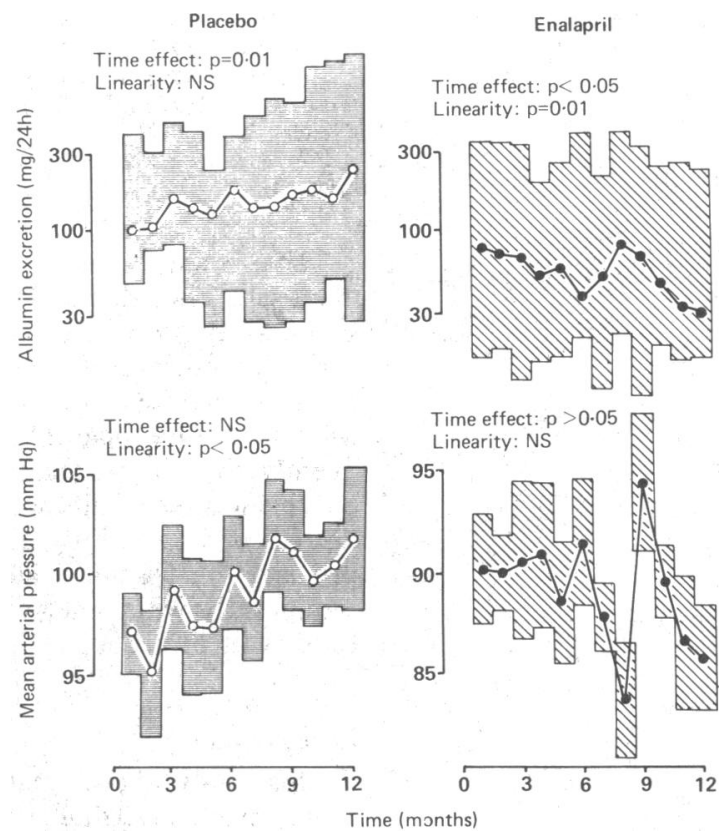

FIG 1-Median (range) logarithm of albumin excretion (upper panels) and mean (SEM) arterial pressure (lower panels) in 10 patients treated with placebo (left panels) and 10 treated with enalapril (right panels). Shaded areas correspond to range and SEM values respectively

months of the study three of the 10 patients receiving placebo had persistent macroalbuminuria, and the seven others continued to have persistent microalbuminuria. None of the 10 patients receiving enalapril had persistent macroalbuminuria; five continued to have persistent microalbuminuria and five showed normal albumin excretion in two or all of the three measurements (Mann-Whitney U test, $\mathrm{p}=0.005$ ).

Mean arterial pressure was identical between the groups during the pretreatment period $\left(\mathrm{F}_{18}^{1}=0 \cdot 10\right.$; $\mathrm{p}>0.5)$ and it was significantly lower during treatment with enalapril than placebo $\left(\mathrm{F}_{18}=10.43, \mathrm{p}<0.005\right)$. A significant interaction occurred with the duration of treatment $\left(\mathrm{F}_{198}^{11}=2 \cdot 16, \mathrm{p}<0 \cdot 05\right)$. The mean arterial pressure increased linearly with placebo but was not significantly changed with enalapril (fig 1 , lower 
panels). Mean albumin excretion and mean arterial pressure were calculated in all patients for the pretreatment period and for the last three months of the trial. With placebo, but not enalapril, the difference in these variables between these two periods was significantly correlated (fig 2).

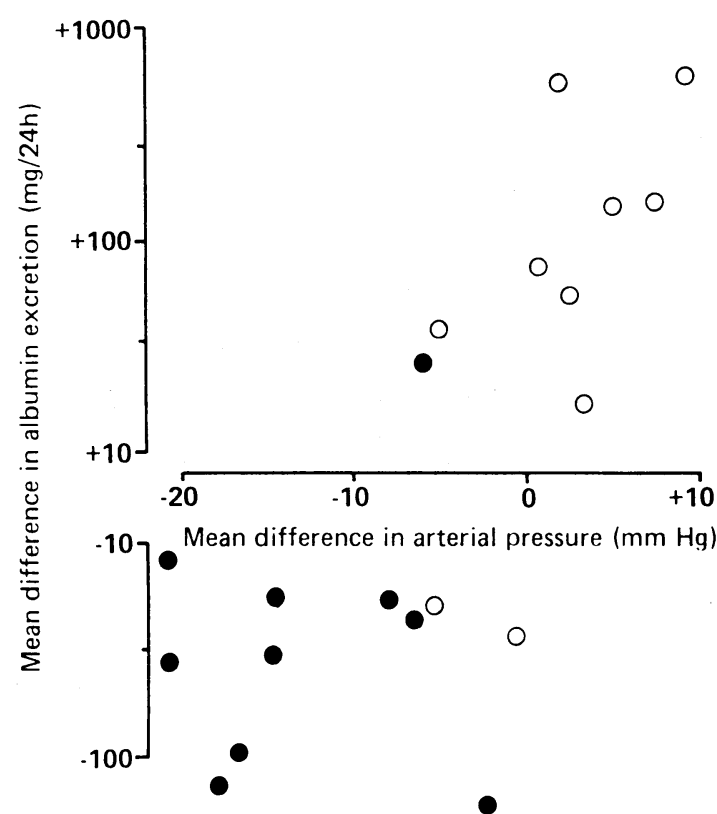

FIG 2-Relation between the individual differences in mean arterial pressure and in albumin excretion rate between pretreatment period to last three months of trial in 10 patients receiving placebo $(\mathrm{O})$ and 10 receiving enalapril $(\mathbf{O})$.

Placebo: $r=0 \cdot 71, p<0 \cdot 05$. Enalapril: $r=0 \cdot 00, \mathrm{NS}$. (Spearman's rank test)

Table II shows kidney function in patients during the trial. The glomerular filtration rate decreased significantly with placebo over the one year study period but not with enalapril. Conversely, the effective renal plasma flow rose increasingly and significantly with time with enalapril but not with placebo. Consequently, the filtration fraction decreased with enalapril, but this was not significant. The total renal resistances decreased progressively and significantly with enalapril and the fractional albumin clearance improved significantly with time, whereas it worsened significantly with placebo.

\section{Discussion}

This study shows that long term inhibition of angiotensin converting enzyme in diabetics with persistent microalbuminuria but without hypertension can prevent the diabetic nephropathy that occurs otherwise with conventional antidiabetic treatment. The glomerular permeability to albumin and the resistances of the renal vasculature improved increasingly with time with enalapril. Conversely, progressive and parallel increases in albumin excretion and mean arterial pressure occurred with placebo. Thus we cannot state that inhibition of angiotensin converting enzyme has a specific effect on albumin excretion by reducing pressure within the glomeruli independently of its effects on systemic blood pressure. ${ }^{7}$

The changes in albumin excretion could be attributed solely to changes in blood pressure or inhibition of the converting enzyme, or both. Other factors that may have affected these variables are changes in weight, ${ }^{21}$ protein intake, ${ }^{22}$ sodium balance, or metabolic control. ${ }^{23}$ These were discounted as weight, excretion of urea and sodium, and $\mathrm{HbA}_{\mathrm{lc}}$ and mean plasma glucose concentrations were constant throughout the study. Also our results cannot be explained by the high variability in albumin excretion ${ }^{24}$ as this variable was measured before and during treatment.

We have reported reduced albumin excretion and blood pressure after six months of treatment to inhibit angiotensin converting enzyme. " This might have been the consequence of the physical reduction in hydraulic pressure proximal to the glomerular basement membrane as the differences between the treated patients and controls were significantly related to the type of treatment, but its duration was not significant. In incipient diabetic nephropathy albumin excretion and fractional albumin clearance can be reduced by a rapid decrease in blood pressure - that is, over hours of observation. ${ }^{25}$ Short term manipulation of the haemodynamics within the kidney can have similar consequences through redistribution of renal plasma flow with the opening up of additional glomeruli and capillary loops. This may explain the results of giving patients with incipient diabetic nephropathy a prostaglandin inhibitor ${ }^{26}$ and the acute renal effects of captopril. ${ }^{27}$ We have given patients with incipient diabetic nephropathy enalapril for a short (four day) period, and they did not show significant changes in their fractional albumin clearance, though their mean arterial pressure was reduced and their effective renal plasma flow was increased. ${ }^{28}$ Conversely, albumin excretion and fractional albumin clearance improved progressively in the present study during the follow up. These results can be explained only by a progressive amelioration of the permeability of the glomerular basement membrane to albumin. This is consistent with the observations of Zatz et al in diabetic rats during an experimental study of similar design. ${ }^{29}$

This study shows that inhibition of converting enzyme improved kidney function during the course of diabetic nephropathy, but changes in renal morphology were not studied. Alterations in structure and function in diabetic nephropathy can be dissociated from each other, although mesangial expansion and glomerulosclerosis are usually related to albumin excretion and glomerular filtration rate. ${ }^{30}$ The progressive amelioration of total renal resistances and of fractional albumin clearance reported here may be explained by accompanying changes in kidney morphology. In diabetic rats the increases in glomerulosclerosis and albumin excretion were reduced by inhibition of converting enzyme.

TABLE II -Median (range) measures of kidney function during trial in normotensive diabetics receiving enalapril or placebo ${ }^{\star}$

\begin{tabular}{|c|c|c|c|c|c|c|c|c|c|c|}
\hline & \multicolumn{2}{|c|}{$\begin{array}{l}\text { Glomerular filtration rate } \\
\left(\mathrm{ml} / \mathrm{min} / 1 \cdot 73 \mathrm{~m}^{2}\right)\end{array}$} & \multicolumn{2}{|c|}{$\begin{array}{l}\text { Effective renal plasma flow } \\
\left(\mathrm{ml} / \mathrm{min} / 1 \cdot 73 \mathrm{~m}^{2}\right)\end{array}$} & \multicolumn{2}{|c|}{$\begin{array}{l}\text { Filtration fraction } \\
\qquad\left(\times 10^{-3}\right)\end{array}$} & \multicolumn{2}{|c|}{$\begin{array}{l}\text { Total renal resistances } \\
(\mathrm{mm} \mathrm{Hg} / \mathrm{ml} / \mathrm{min})\end{array}$} & \multicolumn{2}{|c|}{$\begin{array}{l}\text { Fractional albumin clearance } \\
\qquad\left(\times 10^{-6}\right)\end{array}$} \\
\hline & Placebo & Enalapril & Placebo & Enalapril & Placebo & Enalapril & Placebo & Enalapril & Placebo & Enalapril \\
\hline 0 Month & $129(104-195)$ & $131(90-158)$ & $564(458-858)$ & $547(347-722)$ & $225(192-243)$ & $250(186-349)$ & $0.19(0 \cdot 11-0.45)$ & $0.23(0 \cdot 14-0 \cdot 34)$ & $11 \cdot 4(4 \cdot 0-44 \cdot 5)$ & $18 \cdot 6(3 \cdot 7-64 \cdot 0)$ \\
\hline 6 Months & $122(94-164)$ & $137(104-180)$ & $603(362-827)$ & $538(432-852)$ & $214(190-264)$ & $226(168-354)$ & $0.20(0.12-0.47)$ & $0 \cdot 18(0 \cdot 10-0 \cdot 23)$ & $24 \cdot 8(6 \cdot 2 \cdot 56 \cdot 8)$ & $5 \cdot 6(2 \cdot 4-46 \cdot 4)$ \\
\hline 12 Months & $109(80-192)$ & $124(110-234)$ & $568(308-869)$ & $684(381-1204)$ & $221(183-260)$ & $199(152-318)$ & $0 \cdot 19(0 \cdot 12-0 \cdot 38)$ & $0.14(0.09-0.28)$ & $41 \cdot 9(4 \cdot 1-219 \cdot 7)$ & $3 \cdot 6(2 \cdot 0-13 \cdot 9)$ \\
\hline Time effect $F_{9}^{1}$ & 3.75 & $1 \cdot 12$ & 0.81 & $9 \cdot 68$ & 0.08 & 2.83 & 0.11 & $16 \cdot 41$ & $9 \cdot 20$ & $40 \cdot 90$ \\
\hline p & $<0.05$ & $>0 \cdot 1$ & $>0.1$ & 0.001 & $>0.5$ & $>0.05$ & $>0.5$ & 0.0001 & 0.01 & 0.001 \\
\hline Tail probability (p): & & & & & & & & & & \\
\hline Between group & \multicolumn{2}{|c|}{$>0 \cdot 1$} & \multicolumn{2}{|c|}{$>0.5$} & \multicolumn{2}{|c|}{$>0 \cdot 1$} & \multicolumn{2}{|c|}{$>0 \cdot 1$} & \multicolumn{2}{|c|}{$<0.05$} \\
\hline Time interaction & \multicolumn{2}{|c|}{0.05} & \multicolumn{2}{|c|}{0.001} & \multicolumn{2}{|c|}{$>0 \cdot 1$} & \multicolumn{2}{|c|}{0.01} & \multicolumn{2}{|c|}{$<0.001$} \\
\hline
\end{tabular}


In our study albumin excretion and mean arterial pressure rose in parallel during treatment with placebo for one year and were significantly correlated. This is consistent with observations on similar patients who did not receive antihypertensive treatment for two years, ${ }^{7}$ but in both studies the diabetics with persistent microalbuminuria and hypertension were eliminated. Thus too few patients with persistent microalbuminuria were studied to estimate the incidence of diabetic nephropathy. Also the means by which inhibition of converting enzyme can modify this incidence requires studies of many patients. Nevertheless, microalbuminuria in diabetics is associated with a significant increase in blood pressure compared with controls. ${ }^{31} 32$ Taken together these data support the view that a slight rise in blood pressure occurs in diabetics together with microalbuminuria progressing to macroalbuminuria and suggest that antihypertensive treatment should be instituted early in diabetics compared with normoglycaemic hypertensive patients. ${ }^{33}$

We cannot conclude from our results whether the observed reduction in albumin excretion can be related to reduction of blood pressure systemically or to reduction of that within the glomeruli specifically due to inhibition of the converting enzyme. In azotemic diabetics the addition of captopril to conventional antihypertensive treatment has been claimed to give short term reduction in heavy proteinuria without any further reduction in blood pressure. ${ }^{34}$ On the other hand, another study on treatment of hypertension with captopril in diabetic nephropathy showed that a reduction in urinary albumin excretion was accompanied by a reduction in blood pressure.$^{35}$ In non-diabetic rats proteinuria due to hypertension was prevented by enalapril but not by conventional antihypertensive triple treatment, though blood pressure was reduced equally in both treatments. ${ }^{36}$ Conversely, Bank et al presented experimental evidence against the hypothesis of increased glomerular pressure as a determinant in initiating diabetic nephropathy but showed in the same study that lowering blood pressure to hypotensive values in diabetic rats protected against early diabetic nephropathy. ${ }^{37}$

No data are yet available in human diabetics in favour of a beneficial effect of inhibition of converting enzyme on albumin excretion independently of its hypotensive effect. Studies in diabetics with microalbuminuria should compare the long term effects of inhibitors of angiotensin converting enzyme with those of other antihypertensive drugs.

We thank Nuno Luis and Annie and Michel Depardieu for their technical help, and Nicole Braure and Florence Lopez for their secretarial help. The study was supported by the Université Paris VII, the Association Claude Bernard, and Merck Sharp and Dohme, France.

1 Andersen AR, Christiansen JS, Andersen JK, Kreiner S, Deckert T. Diabetic nephropathy in type 1 (insulin-dependent) diabetes: an epidemiological study. Diabetologia 1983;2:496-501.

2 Mogensen CE. Microalbuminuria predicts clinical proteinuria and early mortality in maturity onset diabetes. $N$ Engl f Med 1984;310:356-60.

3 Mogensen CE, Christensen CK, Vittinghus E. The stages in diabetic renal disease. With emphasis on the stage of incipient nephropathy. Diabetes 1983;32(suppl 2):64-78.

4 Parving HH, Viberti GC, Keen H, Christiansen JS, Lassen NA. Hemodynamis factors in the genesis of diabetic microangiopathy. Metabolism 1983;32:943-9.

5 Mogensen CE, Christensen CK. Predicting diabetic nephropathy in insulindependent patients. $N$ Engl f Med 1984;311:89-93.

6 Wiseman MJ, Saunders AJ, Keen H, Viberti GC. Effect of blood glucose control on increased glomerular filtration rate and kidney size in insulindependent diabetes. N Engl F Med 1985;312:617-21.

7 Feldt-Rasmussen B, Mathiesen ER, Deckert T. Effect of two years of strict metabolic control in progression of incipient nephropathy in insulindependent diabetes. Lancet 1986;ii:1300-4.

8 Diabetes Control and Complications Trial (DCCT) Research Group. The diabetes control and complications trial (DCCT). Design and methododiabetes control and complications trial (DCCT). Design and method

9 Wiseman MJ, Bognetti E, Dodds R, Keen H, Viberti GC. Changes in renal function in response to protein restricted diet in type 1 (insulin-dependent) diabetic patients. Diabetologia 1987;30:154-9.

10 Christensen CK, Mogensen CE. Effect of antihypertensive treatment on progression of incipient diabetic nephropathy. Hypertension 1985;7(suppl II): $109-13$.

11 Marre M, Leblanc H, Suarez L, Guyenne TT, Menard J, Passa P. Converting enzyme inhibition and kidney function in normotensive diabetic patients with persistent microalbuminuria. Br Med f 1987;294:1448-52.

12 Mogensen CE, Chachati A, Christensen CK, et al. Microalbuminuria: an early marker of renal involvement in diabetes. Uremia Investigation 1985-86:9: $85-95$

13 Joint National Committee on Detection, Evaluation, and Treatment of High Blood Pressure. The 1984 report of the joint national committee on detection, evaluation, and treatment of high blood pressure. Arch Intern Med 1984;144:1045-7.

14 Mogensen CE. Long term antihypertensive treatment inhibiting progression of diabetic nephropathy. $B r$ Med $\mathcal{F}$ 1982;285:685-8.

15 Parving HH, Andersen AR, Smidt UM, Svendsen PAA. Early aggressive antihypertensive treatment reduces rate of decline in kidney function in diabetic nephropathy. Lancet 1983;ii:1175-9.

16 Parving HH, Andersen AR, Smidt UM, Hommel E, Mathiesen ER, Svendsen PA. Effect of antihypertensive treatment on kidney function in diabetic nephropathy. Br Med $\mathcal{F}$ 1987;294:1443-7.

17 Christensen CK, Orskov C. Rapid screening PEG radioimmunoassay for quantification of pathological albuminuria. Diabetic Nephropathy 1984;3: $92-4$

18 Mogensen CE. Glomerular filtration rate and renal plasma flow in short-term and long-term juvenile diabetes mellitus. Scand f Clin Lab Invest 1971; 28:91-100.

19 Menard J, Guyenne TT, Corvol P, Pau B, Simon D, Roncucci R. Direct immunometric assay of active renin in human plasma. $\mathcal{f}$ Hyperten 1985 3(suppl 3):275-8.

20 Dixon WJ, Brown MB, Engelman N, et al. Biomedical programs statistical software. Berkeley, California: University of California Press, 1983.

21 Vasquez B, Glock EV, Savage PJ, et al. Sustained reduction of proteinuria in type 2 (non insulin-dependent) diabetes following diet induced reduction of hyperglycaemia. Diabetologia 1984;26:127-33.

22 Zatz R, Meyer TW, Rennke HG, Brenner BM. Predominance of hemodynamic rather than metabolic factors in the pathogenesis of diabetic glomerulopathy. Proc Natl Acad Sci USA 1985;82:5963-7.

23 Hanssen KF, Dahl-Jorgensen K, Lauritzen T, Feldt-Rasmussen B, Brinchmann-Hansen O, Deckert T. Diabetic control and microvascular complications: the near normoglycaemic experience. Diabetologia 1986;29:677-84.

24 Feldt-Rasmussen B, Mathiesen ER. Variability of urinary albumin excretion in incipient diabetic nephropathy. Diabetic Nephropathy 1984;3:101-3.

25 Hommel E, Mathiesen E, Edsberg B, Bahnsen M, Parving HH. Acute reduction of arterial blood pressure reduces albumin excretion in type 1 (insulin-dependent) diabetic patients with incipient nephropathy. Diabetologia 1986;29:211-5.

26 Hommel E, Mathiesen E, Arnold-Larsen S, Edsberg B, Olsen UB, Parving $\mathrm{HH}$. Effects of indomethacin on kidney function in type 1 (insulindependent) diabetic patients with nephropathy. Diabetologia 1987;30:78-81.

27 Elving LD, Wetzels JFM, de Nobel E, Hoitsma AJ, Berden JHM. Diabetic nephropathy: acute effects of captopril on renal haemodynamics and albuminuria [Abstract]. Diabetologia 1987;30:517A.

28 Marre M, Leblanc H, Passa P. A short-term reduction of blood pressure does not modify glomerular permeability to albumin in diabetic patients with incipient nephropathy [Abstract]. Diabetic Complications 1987;87(Oct): 29-31.

29 Zatz R, Dunn BR, Meyer TW, Anderson S, Rennke HG, Brenner BM. Prevention of diabetic glomerulopathy by pharmacological amelioration of glomerular capillary hypertension. $\mathcal{F}$ Clin Invest 1986;77:1925-30.

30 Mauer SM, Steffes MW, Ellis EN, Sutherland DER, Brown DM, Goetz FC. Structural-functional relationship in diabetic nephropathy. $\mathcal{f}$ Clin Invest 1984;74:1143-55.

31 Mathiesen E, Saubrey N, Hommel E, Parving HH. Prevalence of microalbuminuria in children with type 1 (insulin-dependent) diabetes mellitus. Diabetologia 1986;29:640-3.

32 Marre M, Passa P. Prevalence of microalbuminuria in the diabetic clinic. In: Mogensen CE, ed. The kidney and hypertension in diabetes. Boston: Martinus Nijhoff, 1988:51-8

3 Mogensen CE. Microalbuminuria as a predictor of clinical diabetic nephropathy. Kidney Int 1987;31:673-89.

34 Taguma Y, Kilamoto Y, Futaki G, et al. Effect of captopril on heav proteinuria in azotemic diabetics. $N$ Engl F Med 1985;313:1617-20.

35 Hommel E, Parving HH, Mathiesen E, Edsberg B, Nielsen MD, Giese J. Effect of captopril on kidney function in insulin-dependent diabetic patients with nephropathy. BrMed f 1986;293:467-70.

36 Anderson S, Rennke HG, Brenner BM. Therapeutic advantage of converting enzyme inhibitors in arresting progressive renal disease associated with systemic hypertension in the rat. F Clin Invest 1986;77:1993-2000.

37 Bank N, Klose R, Aynediian HS, Nguyen D, Sablay LB. Evidence against increased glomerular pressure initiating diabetic nephropathy. Kidney Int 1987;31:898-905.

(Accepted 20 fune 1988) 